\title{
26
}

\section{Standard-Setting in Colonial Labour Regulation and the Great Depression}

\section{Heiner Fechner}

The Great Depression (1929-1939) can be seen as an international turning point in labour regulation in the colonies of European imperial powers in Sub-Saharan Africa. The context of the Great Depression essentially marked the beginning of the end of the era of post-slavery labour "marketmaking", witnessing the move away from forced labour, first steps towards protection of employees and changes in form, length, administrative and penal framing of individual labour relations as well as a more generalised move towards collective labour relations and worker protection. By contrast to early legislation, but also due to path dependency, this phase, ending in the pre-independence years after World War II, highlights the racist and hardly emancipatory roots of modern labour relations in the European colonies.

In the following, the main features of labour-related legislation and changes to it, reflecting modes of production, racial labour relations, the changing role of colonial administration and the contribution of the

H. Fechner $(\bowtie)$

University of Bremen, Bremen, Germany

e-mail: hfechner@uni-bremen.de

(C) The Author(s) 2022 
International Labour Organization to legal developments especially in British, French and German Sub-Saharan colonies will be traced.

\section{Labour Between the Abolition of Slavery and Market Making}

At the beginning of the imperial conquest of heartland Africa in the 1870 s, large parts of the continent were marked by a "slave mode of production" (Lovejoy 2012, 267-271), in other words, non-capitalist economies depending upon slave labour. The European slave trade to the Americas had not only led to a demographic bloodletting affecting an estimated 12.8 million Africans (Lovejoy 2012, 19), but also contributed strongly to the forms and extent of slavery in Africa, where especially, but not exclusively in Islamic territories slavery was of fundamental relevance. Although the slave trade and slavery had formally been abolished in the British (Slave Trade Act 1807 and Slavery Abolition Act 1833) and French (Decree of the Abolition of Slavery, April 27 1848) colonies, the legal construction of colonisation in most African territories avoided the immediate and complete abolition of slavery.

European imperial powers used slavery as a central pretext for conquering Africa, claiming the necessity to protect indigenous peoples from slavery via "protectorates". Slavery was also used as a pretext for the development of socio-economic relations, as can be read between the lines in international treaties like the treaty on the prohibition of slave trade adopted by European imperial nations (General Act of Brussels, 1890) which included the Western duty to "support (...) the native population, (...) to initiate them in agricultural labor and in the industrial arts so as to increase their welfare; to raise them to civilization and bring about the extinction of barbarous customs" (Article II).

If the international formula to raid Africa was thus the advertisement of a combination of "protection" and "development", this "justified" extensive use of the territorial and human productive sources for the generation of revenues, including export orientation. For the long-term member of the British Colonial Office, Lord Olivier, 
practically the whole of our recent colonisation in Africa (...) has been essentially capitalist colonisation (...), financed by European syndicates and investors, and the active directing work of it done by men who go out as landowners or farmers and employers and organisers of labour, the labour which they expect to employ being not specifically chattel slave labour, but the labour of native black men. (Olivier 1929, 14)

The abolition of slavery hardly played an important role in the immediate winning of waged workers. First, certain traditions of slavery in the Muslim world as complex systems of rights and duties including social security in case of sickness, old age, the impossibility of dismissal were often even more "attractive" for slaves than "free labour" for low wages in short-term contracts. Second, in most colonies metropolitan administrations were little engaged in actively ending slavery. In order to avoid conflicts with slave owners, colonisers prohibited slave trade and enslavement, but left existing slavery largely untouched, partially regulating only rights and duties of slaves and slave owners (for the German case, see Zorn 1913, 479-495). Often "anti-vagrancy" legislation was used to return escaped slaves to their masters, while slavery was respected and even enforced as traditional indigenous law (Lovejoy 2012, 259-266). With the introduction of capitalist economies and the prohibition of slave trading and enslavement, the "slave mode of production" in all European colonies was successively, but not at once replaced by capitalist economies with special colonial features.

\subsection{Forced and Compulsory Labour}

Since the sale of the capacity to work had no tradition in rural Africa, wages and working conditions offered by European settlers and investors were bad and the indigenous people hardly identified themselves with the European conquerors; in most territories where a workforce was needed, supply ran short of demand. For their own administrative interests, but in early colonialism also at least de facto in the interest of private actors, all European colonial administrations introduced legislation for almost 
all territories that permitted the use of forced or compulsory labour, although with differing content (ILO 1929).

Forced labour was regulated and used differently for general public, local public and private purposes. The first group included public works like the construction of roads and railways, harbours, telegraph and telephone lines, or public buildings; porterage; compulsory labour in emergencies like famines or infectious diseases; compulsory cultivation of trees for reforestation or cash crops for exports, and other purposes decided by the administration (ILO 1929, 22-138). To illustrate the importance of these tasks in terms of manpower: in 1908, German administrators estimated some 36-40,000 porters just in the recently founded Yaoundé district in Cameroon, mostly transporting rubber, without differentiating between compulsory and free labour (Reichstag-Drs. 271, 597).

With regard to local public purposes, unpaid compulsory labour was regulated by a diverse set of rules (ILO 1929, 139-189). In their standardsetting, all colonisers typically foresaw up to one month of such unpaid labour for men of workable age. The work was often restricted to building and maintenance of communication infrastructure, and frequently could be commuted to money payments, thus being defended by some governments as a form of taxation.

The use of forced labour for private means existed in most colonies in Africa during early imperial colonialism. Sometimes this was openly regulated by law like in Botswana ("Bechuanaland"), where Sec. 115 of the Prison Regulations, 1927 ruled that "(e)very prisoner shall be employed every day in such work as the magistrate may direct", with the special provision that this should not result in privileges for public administration, as laid down in Sec. 117: "Government officials shall not employ prison labour for private purposes, except on payment and on the same terms and conditions as private individuals are allowed the services of prisoners." In French colonies, colonial administrations made use of forced labour not only for public works but also for private employers (Cooper 1996; Maul 2007, 479).

European recruiters not only in British colonies often made use of systems of indirect control based on "native authorities' ordinances", which provided for the institutionalisation of indigenous administrators ("chiefs") as partially self-governing actors with certain duties, but also 
several privileges. "(T)he British policy is to rule subject races through their own chiefs," the former governor of Nigeria, Frederick Lugard (1922, 194) quoted Lord Alfred Milner, one of the masterminds of British imperial policy. A common way to effectively obtain compulsory labour for "free labour contracts" was for public authorities to ask chiefs, or for private agents to bribe chiefs, to produce a certain number of men (Lugard 1922, 412; Okia 2019).

In agricultural enterprises owned by European settlers, especially in British colonies, contracts resembling medieval serfdom were still widespread in the first half of the twentieth century. In South Africa, Kenya and Nyasaland (today Malawi), laws regulated the exchange of indigenous workers' labour for their use of land owned by the European settlers. "Labour tenants" thus bound themselves with their families to work for the "employer-landlord" a certain number of days per year-for example-between 180 and 270 in Kenya (ILO 1937, 21-22). Furthermore, France used forced recruiting for military service as a pretext to employ a part of the military recruits as so-called deuxième portion du contingent for any work under military supervision (Maul 2007, 479).

\section{Compulsion to "Free" Labour}

Especially in the 1920s, the shortage of labour evolved as a central issue for economic growth in Sub-Saharan Africa (Hailey 1938; Orde Browne 1967 (1933)). In order to obtain "free labour", the threat of force was rapidly expanded to a complex, effectively differentiated system of incentives to participate in waged labour. Central instruments were the taxing of indigenous males, the more or less forced "inducement" to work by local administration by means of indirect control, the introduction of passes and registration of workers, and finally the registration of labour contracts and their enforcement with the threat of fees and imprisonment in case of abandonment, as well as damages. Administration, legislation and missionary work equally position women in traditional community relations and the subsistence economy. Women assumed the work of males who left their village temporarily and also had the role of 
upholding traditional order, whereas men were expected to serve colonial labour interests.

Since the late 1890s, a central instrument in most colonies for inducing men to work was the introduction of hut taxes and later also poll taxes. Hut taxes taxed men who owned their own hut, whereas poll taxes had to be paid by men of workable age independently of hut ownership. These taxes implied the need to participate in a money-based economy, either by labour or by means of self-employment, especially by producing cash crops. Instead of payment, several pieces of legislation allowed the performance of (public) labour, varying roughly between eight days and one month per year. When contractual work for European employers surpassed minimum thresholds, taxes often were reduced (Lugard 1922, 256).

For the case that working conditions did not meet the expectations of the men induced to work, long-duration fixed-term contracts with restricted rights to termination were reinforced by rules forcing employees to stay at work. Laws designed to control the movement of indigenous people within and beyond the borders of colonies aimed to avoid desertion in many colonies. In "German South West Africa” (Namibia), ordinances from 1907 introduced the obligation for indigenous people to register and always carry their registration marks with them. No labour contract could be concluded without a registration mark. Those who were not able to produce their registration marks and could not prove waged or self-employment were treated as "vagabonds" and were subject to punishment, including fines, imprisonment and forced labour. In Kenya, the 1915 Registration of Natives Ordinance, put into effect in 1920, introduced a workbook (kipande), keeping track of all labour relations, which every men of workable age had to carry with him in a metal case around his neck (Okia 2019, 28-29).

In conjunction with long-duration fixed-term contracts, labour pass systems also helped to keep wages low, as employers attracted workers to sign contracts by paying attractive advances and then paying low "local rate" wages afterwards, using the pass system to avoid desertion (Anderson 2000, 477). Wages could typically be kept below subsistence levels, since labour relations were not designed to generate "living wages", but rather fulfil the cash needs of families and communities primarily depending on 
a subsistence economy, using labour migration for seasonal or otherwise short- or fixed-term contracts (ILO 1946, 37).

\section{Colonial Labour Legislation}

French colonial law on indigenous employment contracts in African colonies before the Great Depression typically differentiated between day labourers and permanent contracts, essentially regulating only the second category (Le Crom et al. 2017). The same is true for British colonies and German colonies. In early French colonial law, only fixed-term contracts are called labour contracts. Before the 1930s and often up to the 1950s, colonial labour legislation was designed for African workers only.

The content and complexity of colonial regulation on the one hand, and the similarity of norms on the other, can be seen in the French Equatorial African Labour Decree of 1911, compared with the British Kenyan Employment of Natives Ordinance 1910 and the German Cameroon Labour Ordinance 1909. Contracts with a minimum duration of more than one or three months had to be in written form, made before a colonial official or at least publicly approved and registered. Health status had to be checked, in the French and British cases by a physician. Fixed-term contracts in the latter cases were restricted to two years, but renewable without limitation. In the French case, a maximum working time of ten hours per day was set, in all cases a free Sunday was guaranteed. The kind of payment of wages, food and accommodation was specified (not the amount!), as were physical provisions in case of sickness. Finally, all three laws contain rules concerning the costs of return to the worker's place of origin.

A major formal difference between French legislation on the one hand, British and some German legislation on the other hand was the provision of penalties in case of desertion from work for the latter two. Although penalties had a long tradition in British labour legislation, when introduced in African colonies beyond South Africa at the beginning of the imperialist epoch, the penalty as a decisive feature had been abolished by a set of laws between 1867 and 1875 in Great Britain itself (Hay and Craven 2005). In Britain, penalties had been used in the nineteenth 
century to suppress collective action. The upcoming trade unions had successfully campaigned for abolishing imprisonment for strike activities. Penalties for desertion were harsh. In the case of "German South West Africa" (Namibia), for example, the 1909 Law concerning Penalties for Natives because of Breach of Contract ordered chained imprisonment up to three months with or without corporal punishment or fines.

French labour law concerning breach of contract was restricted to the payment of damages, keeping civil and criminal law formally distinguished. In practice, nonetheless, the French indigenat laws which were valid in all exploitative colonies were used to punish workers for breaches of contract such as desertion, since workers liable to pay damages for breach of contract or fines for lack of resources usually could not pay. The colonial state in this case often resorted to forced labour during imprisonment (Asiwaju 1978).

Colonial labour legislation before the 1930s thus is centred around fixed-term contracts and recruitment of fixed-term workers. Casual contracts were hardly regulated, "normal" labour contracts were restricted in duration to the pay period, although automatically renewable. Exaggerating slightly, early colonial labour legislation could be described in today's language as the regulation of the posting of workers, of labour migration and of private employment agencies. Fixed-term contracts were designed especially for seasonal work in plantations and temporary work in mines. Especially male workers were expected to leave and return to their villages, to live mostly from a subsistence economy and use waged labour for partial participation in the money economy, especially in order to pay taxes.

The set of regulations essentially concerned "able-bodied males" who were expected to pay taxes, work away from their villages for limited periods of several months to a few years, and return with some money to be dedicated to European products. The women (together with older and weaker men and children) were expected to supply the food in the subsistence economy and take care of the families' and communities' social reproduction. Labour regulation thus did not start as a means for the protection of workers, but as an administrative tool for the control and "quality management" of domestic or inner-African migration processes for labour supply on the one hand and "sustainable development" of 
rural areas on the other hand. The structural difference between employer and employee, the raison d'être of worker-protective labour legislation, was tipped even more towards the employers' side with the help of compulsory measures. Protective measures concerning health and minimum living conditions are aimed at the public interest in sustainability and health management rather than workers' protection. Protective norms concerning the use of time and fair remuneration, or restricting the use of the workforce, hardly existed, nor could collective agency fill these gaps. Collective action was prohibited, and migratory fixed-term labour relations made unionising practically impossible. Private and public labour relations in this phase comprised a wide range of legal constructions including slave, forced, pawn, indentured and free labour in conditions typically marked by colonial legal pluralism.

\section{$4 \quad$ Economic Crisis and Changes in Labour Regulation}

In 1932, the Governor of Kenya introduced an ordinance which regulated the mechanism to introduce minimum wages for any occupation and territory (No. 22 of 1932). In the same year, an ordinance to regulate and control compulsory labour (No. 42 of 1932) was enacted, introducing strong material and procedural limits to the use of forced labour, including mandatory pay equivalent to voluntary payment. In 1937, under the Trade Unions Ordinance collective workers' organisations were legalised. Finally, in 1938 the Employment of Natives Ordinance was repealed and replaced by the Employment of Servants Ordinance.

Comparable legislative changes could be observed in British colonies in large parts of Sub-Saharan Africa. Minimum wage mechanisms were introduced in most British colonies, as was trade union legislation. In French West Africa, in 1937 minimum wages were introduced, trade unions were legalised, collective agreements and labour conflicts were regulated (Ehrentraut 1973, 79-83).

The 1930s and thus the context of the Great Depression can be seen as a turning point in African colonial labour legislation, where forced labour 
was put on the path to abolition, and worker protection was slowly introduced. From a factual perspective, the socio-legal situation changed rapidly during the Great Depression, nonetheless hardly due to the impact of new legislation. The worldwide economic crisis led to a severe diminution of export prices for cash crops and minerals. Trying to compensate for falling export taxes, poll taxes tended to increase, while companies reduced their staff and the wages paid to indigenous workers. Rural exodus towards slums began, with sufficient labour supply for public and private employers, and social unrest grew. As a consequence of economic and tax political developments, forced labour ceased to be a macroeconomic means, although its communal relevance remained (Cooper 1996).

As the (originally bad) social situation of "free" African workers rapidly deteriorated and legislative changes showed rather a cosmetic character, the enactments in British and French territories reflect foremost the changes in political orientation and majorities in the metropolitan countries, the trade union movement and especially the International Labour Organization. Illustrative for this direction is the European Workers' Charter for Coloured Labour passed by the Labour and Socialist International Congress in 1928. Among other things, it demands the abolition of enforced labour as well as taxation and other pressures aiming at forcing indigenous people into employment, as well as the abolition of enforcing employment contracts under sanctions of penal law, and the regulation and inspection of the recruiting and labour conditions "as to prevent industrial slavery and the economic dislocation of the life of the village and tribal communities" (Olivier 1929, 323).

Social democratic parties and trade unions in particular carried these views into governments and the ILO. The perspective on local conditions in the colonies thus seemed to depend strongly on the government in charge: major changes took place in British colonies during the two governments led by Ramsay MacDonald (the Labour government 1929-1931 and the multiparty coalition called the National Government 1931-1935), whereas for French colonies changes were initiated by the Popular Front Government led by Léon Blum, aiming to introduce equal rights for workers in all French colonies. A major factor in the search for consensus in improving labour conditions in the colonies, and thus paving the road for "progressive" governments, was the ILO. 
The introduction of minimum wage legislation was related to ILO's 1928 Minimum Wage-Fixing Machinery Convention C026, ratified by the UK in 1929, and by France in 1930. According to Article 35 of the ILO Constitution (Article 421 of the Treaty of Versailles), members "engaged" to apply ratified conventions in colonies, protectorates and other dependencies, except if they were inapplicable due to local conditions. The UK reacted by introducing the possibility of minimum wages, while de facto minimum standards were only introduced during World War II, by which time trade unions had developed in most colonies. In French Occidental Africa, on the other hand, in 1937 decree No. 259 provided that minimum wages were to be introduced via ordinance by the regional governors.

The French Popular Front government did not intend inclusion for all workers in the colonies, though. The legalisation of trade unions in French Sub-Saharan territories in 1937 contained several conditions. Membership depended on the prerequisite of primary education and fluent French. Furthermore, women needed the written approval of their husbands if married, of the patriarch if unmarried, if they wanted to join trade unions (Ehrentraut 1973, 80).

A more direct impact of ILO can be seen in the case of the Forced Labour Convention C29 of 1930, ratified by the UK in 1931 and by France in 1937. The ILO had been acting at the forefront of a network for passing the convention (Maul 2007). The UK government rapidly adopted anti-forced labour legislation in African colonies where forced labour still existed. For France, on the other hand, which still made use of forced recruitment by the colonial administration for private undertakings in the 1930s, the official acceptance of the convention without ratification before 1937 can be rather seen as fear of the political costs of open opposition (Cooper 1996).

In the context of the Great Depression, the ILO passed its three conventions on indigenous labour: in 1936 the Recruiting of Indigenous Workers Convention (ILO C-50), and in 1939 the Contracts of Employment (Indigenous Workers) Convention (ILO C-64) and the Penal Sanctions (Indigenous Workers) Convention (ILO C-65). Especially C-65 was of fundamental importance for workers in British colonies. The context of the Great Depression helped, since from the 
employers' perspective, recruitment was hardly necessary for at least for some time, and desertion was not a major problem. Especially in this crisis, long-term contracts proved to be comparatively protective for workers, since they could not simply be dismissed by employers.

The effect of the ILO conventions and international discussions was the enduring abandonment of long-term contracts and penal sanctions for breach of contract. The changes only fully took effect after World War II. Nonetheless, the context of the Great Depression opened the path to major reforms in colonial labour legislation after World War II and postcolonial relations.

The discussions in the 1930s thus mark a turning point in labour regulation in the colonies, although they were less protective in fact than on paper. The fundamental inequalities caused by imperialist colonisation in terms of labour, in other words, the fundamentally racist division of labour (unskilled labour for indigenous workers), and gender relations focusing almost exclusively on and privileging men in terms of public and labour-related rights and duties, were not addressed.

Acknowledgements This chapter is a product of the research conducted in the Collaborative Research Center "Global Dynamics of Social Policy" at the University of Bremen. The centre is funded by the Deutsche Forschungsgemeinschaft (DFG, German Research Foundation)—project number 374666841-SFB 1342.

\section{References}

Anderson, David M. 2000. Master and Servant in Colonial Kenya, 1895-1939. The Journal of African History 41 (3): 459-485.

Asiwaju, Anthony Ijaola. 1978. Control Through Coercion; A Study of the Indigenat Regime in French West African Administration, 1887-1946. Journal of the Historical Society of Nigeria 9 (3): 91-124.

Cooper, Frederick. 1996. Decolonization and African Society: The Labor Question in French and British Africa. Cambridge: Cambridge University Press.

Ehrentraut, Erik. 1973. Die Entwicklung des Arbeitsrechts im ehemaligen Französisch-Westafrika: Eine historische und rechtsvergleichende Darstellung unter Berücksichtigung der heutigen Staaten Dahomey, Elfenbeinküste, 
Guinea, Mali, Mauretanien, Niger, Ober-Volta und Senegal. Dissertation, Universität Hamburg.

Hailey, Lord. 1938. An African Survey: A Study of Problems Arising in Africa South of the Sahara. London; New York; Toronto: Oxford University Press. Hay, Douglas, and Paul Craven. 2005. Introduction. In Masters, Servants, and Magistrates in Britain and the Empire, 1562-1955, ed. Douglas Hay and Paul

Craven, 1-58. Chapel Hill: University of North Carolina Press. ILO. 1929. Forced Labour: Report and Draft Questionnaire. Geneva. . 1937. Regulation of Contracts of Employment of Indigenous Workers: Report Prepared for the International Labour Conference, 24th Session 1938. Geneva.

- 1946. Proposed International Labour Obligations in Respect of Non-SelfGoverning Territories: Further Report on Item IV on the Agenda of the Conference: Minimum Standards of Social Policy in Dependent Territories (Provisions Suitable for a Convention). Montreal.

Le Crom, Jean-Pierre, Philippe Auvergnon, Katia Barragan, Dominique BlonzColombo, Marc Boninchi, Ariane Clément, Stéphanie Couderc-Morandeau, Delphine Connes, Bruno Dubois, Augustin Émane, Silvia Falconieri, Farid Lekéal, Sandra Gérard-Loiseau, Corinne Pernet, Florence Renucci, and Dominique Taurisson-Mouret. 2017. Histoire du Droit du Travail dans les Colonies Françaises (1848-1960): Rapport pour la Mission Droit et Justice. Accessed November 15, 2019. https://halshs.archives-ouvertes.fr/halshs01592836/document.

Lovejoy, Paul E. 2012. Transformations in Slavery: A History of Slavery in Africa. 3rd ed. Cambridge: Cambridge University Press.

Lugard, Frederick John Dealtry. 1922. The Dual Mandate in British Tropical Africa. Edinburgh and London: Routledge.

Maul, Daniel Roger. 2007. The International Labour Organization and the Struggle Against Forced Labour from 1919 to the Present. Labor History 48 (4): 477-500.

Okia, Opolot. 2019. Labor in Colonial Kenya After the Forced Labor Convention, 1930-1963. Cham: Palgrave Macmillan.

Olivier, Sydney. 1929. White Capital and Coloured Labour. London: The Hogarth Press.

Orde Browne, Granville. 1967 (1933). The African Labourer. Dublin: Barnes \& Noble.

Zorn, Philipp, ed. 1913. Deutsche Kolonialgesetzgebung: Textausgabe mit Anmerkungen und Sachregister. With the assistance of F.J. Sassen. Berlin: De Gruyter. 
Open Access This chapter is licensed under the terms of the Creative Commons Attribution 4.0 International License (http://creativecommons.org/licenses/ by/4.0/), which permits use, sharing, adaptation, distribution and reproduction in any medium or format, as long as you give appropriate credit to the original author(s) and the source, provide a link to the Creative Commons licence and indicate if changes were made.

The images or other third party material in this chapter are included in the chapter's Creative Commons licence, unless indicated otherwise in a credit line to the material. If material is not included in the chapter's Creative Commons licence and your intended use is not permitted by statutory regulation or exceeds the permitted use, you will need to obtain permission directly from the copyright holder.

(c) (i) 